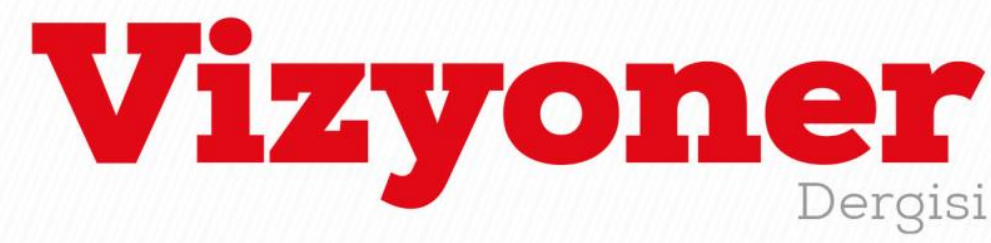

Süleyman Demirel Üniversitesi Vizyoner Dergisi, Yıl: 2020, Cilt: 11, Sayı: Ek, 200-210.

Süleyman Demirel University Visionary Journal, Year: 2020, Volume: 11, No: Supplement, 200-210.

\title{
THE LONG MEMORY BEHAVIOR IN TIME-VARYING BETA: AN EMPIRICAL
} APPLICATION ON BIST*

\section{ZAMANLA DEĞİŞEN BETA KATSAYISINDA UZUN BELLEK DAVRANIŞI: BIST ÜZERINE AMPIRIKK BİR UYGULAMA}

Res. Assist. Hüseyin KESKİN ${ }^{1}$

Assoc. Prof. Dr. İsmail ÇELIK ${ }^{2}$

\begin{abstract}
The study aims to investigate the long memory behavior in time-varying beta, a systematic risk indicator, in İstanbul Stock Exchange (BIST) sub-indices. Using the data regarding BIST national indices, sub-indices and twoyear benchmark bond interest rate between January 2009 and September 2019, the time-varying beta coefficient is determined with DECO-FIGARCH model, and the long memory behaviors of the beta coefficient are analyzed with GPH, Lo R / S and GSP tests. It is found that the beta coefficient of the three sub-indices (banking, financial and industrial) changes over time and the beta coefficient demonstrates long memory behavior (mean-reverting at a hyperbolic speed). It is indicated that the time-varying beta coefficients are forecastable and our findings contradict the weak-form of market efficiency.
\end{abstract}

Keywords: Capital Asset Pricing Model, Systematic Risk, DECO-FIGARCH Model, Long Memory, TimeVarying Beta Coefficient.

JEL Classification Codes: C58, G11.

\section{ÖZ}

Bu çalışmanın amacı Borsa İstanbul alt endekslerinde bir sistematik risk göstergesi olarak kabul gören zamanla değişen beta katsayısında uzun bellek davranışını araştırmaktır. Borsa İstanbul ulusal endeks ve alt endeksleri ile iki yıllık gösterge tahvil faizine ilişkin Ocak 2009 ve Eylül 2019 arasındaki veriler kullanılarak zamana bağlı değişen beta katsayısını DECO-FIGARCH modeli ile tespit etmenin yanı sıra GPH, Lo R/S ve GSP testleriyle beta katsayısının uzun bellek davranışları analiz edilmiştir. Yapılan analizlere göre seçilen üç alt endeksin (bankacılık, mali ve sınai) de beta katsayısının zamana bağlı olarak değiştiği ve beta katsayısının uzun bellek davranışı sergilediği (ortalamasına hiperbolik hızda geri döndüğü) sonuçlarına ulaşılmıştır. Zamana bağlı değişen beta katsayılarının geçmişe bakılarak öngörülebilir olduğu ve bu nedenle de zayıf formda piyasa etkinliğiyle çeliştiği kanıtlanmaktadır.

Anahtar Kelimeler: Sermaye Varlıklarını Fiyatlandırma Modeli, Sistematik Risk, DECO-FIGARCH Modeli, Uzun Hafıza, Zamanla Değişen Beta Katsayısı.

JEL Sınıflandırma Kodları: C58, G11.

\footnotetext{
The study is prepared from the master thesis of Hüseyin KESKIN titled "The Long Memory Behavior in Time-Varying Beta Coefficient: An Empirical Application on BIST" whose supervisor is Assoc. Prof. Dr. İsmail ÇELiK and that is supported defended on 24.09.2019.

1 (D) Mardin Artuklu University, Faculty of Economics and Administrative Sciences, Department of Business Administration, huseyinkeskin@artuklu.edu.tr

2 (D) Burdur Mehmet Akif Ersoy University, Faculty of Economics and Administrative Sciences, Department of Banking and Finance, ismailcelik@mehmetakif.edu.tr

Makale Geliş Tarihi / Received : : 07.05.2020

Makale Kabul Tarihi / Accepted $\quad: 17.11 .2020$ 
Süleyman Demirel Üniversitesi Vizyoner Dergisi, Yıl: 2020, Cilt: 11, Sayı: Ek, 200-210.

Süleyman Demirel University Visionary Journal, Year: 2020, Volume: 11, No: Supplement, 200-210.

\section{INTRODUCTION}

The relationship between return and risk is considered one of the fundamental questions of finance. In recent years, a variety of models explaining how investors measure an asset's risk and link the expected return to this risk, along with practices for the valuation of risk assets have been proposed. Among these models, the Capital Asset Pricing Model (CAPM) developed by Sharpe (1964), Lintner (1965), and Mossin (1966) is considered as the cornerstone of theoretical and empirical finance. The ease of applicability and the ability to explain the systematic risk constituting a significant part of the total risk as a single item are among the most important reasons for preferring CAPM (Elton, Gruber, Brown and Goetzmann, 2014:291). Within the scope of CAPM, the measure of risk to obtain an asset is the beta which demonstrates the sensitivity of the return of financial assets to volatility in the market. CAPM redefines the risk in terms of $\beta$, which holds the non-volatile part of the risk of a stock as a whole relative to the market (Ross, Westerfield and Jaffe, 2013).

The assumption that investors' expectations are homogeneous and as a result the beta value is constant is one of the critical points of discussion about CAPM (Myers, Brealey and Allen, 2014). The basis of the research question of this study is the analysis of whether the beta coefficient values as a systematic risk criterion have changed over time and the beta coefficient changes depending on the conditions, the future beta coefficient values contain fractions of the past (fractional integration).

The hypothesis to be tested in the study is whether the beta coefficient, which is a systematic risk indicator of the sub-indices selected from Borsa İstanbul, changes over time or it has or not a long memory behavior and research of the relationship between time-varying beta and weak-form efficiency in the market.

After giving information about the literature, data, methodology, the analysis's empirical findings will present in the following sections of the study. In the last section, the evaluation of the research and recommendations will give.

\section{LITERATURE}

In his groundbreaking study examining the change in the beta coefficients of all stocks in NYSE between 19261968, Blume (1971) discovered that the portfolio betas tended to regress towards average over time. According to the study, while the correlation between betas for a single asset was low, the correlation between betas for consecutive periods increased as the number of assets in the portfolio increased. That is, the more correlation the calculated betas had, the more predictive power they had. Therefore, it is seen that the beta coefficient of the portfolios consisting of a large number of stocks was quite stable.

Bollerslev, Engle and Wooldridge (1988) indicated that investors' expectations from future returns were dependent on information at a specific time. This indicates a conditional CAPM. Regarding the shortcomings of conditional CAPM, various techniques to predict the time change in beta have emerged in the literature. These techniques are time series models and econometric models. Econometric models are modeled and estimated as a function of economic variables that characterize (theoretically) the beta coefficient to explain time variability.

In their study in which non-financial assets in NYSE and AMEX between 1962 and 1990 were used, Jagannathan and Wang (1996) assumed that beta and market risk premium changed over time. It is observed in the study that the size effect was weakened and the conditional CAPM containing the time-varying beta yielded better results than the unconditional CAPM covering the beta fixedly.

Brooks, Faff and McKenzie (1998) estimated time-varying betas for Australian industry portfolios, using monthly data between January 1974 and March 1996. In this study, three techniques for calculating time-varying betas were examined. Those techniques were the MGARCH model, the Kalman filter and the Schwert and Seguin model. While the evidence in the study based on in-sample and non-sample estimation errors were largely favored the Kalman filter approach, it was concluded that the beta changed over time according to all three techniques.

Faff, Brooks and Ariff (1998) examined whether the beta was fixed for 41 enterprises in the Singapore Stock Exchange in the eight years between 1986 and 1993, using monthly data. They found that the beta changed in $40 \%$ of the assets over time. In addition, the beta changed by approximately $20 \%$ over time for individual assets. In the 
Süleyman Demirel Üniversitesi Vizyoner Dergisi, Yıl: 2020, Cilt: 11, Sayı: Ek, 200-210.

Süleyman Demirel University Visionary Journal, Year: 2020, Volume: 11, No: Supplement, 200-210.

study, it is observed that the length of the sampling period had an effect on the beta, while assets with low beta changed more over time.

Brooks, Faff and McKenzie (2002) searched three different techniques for a time-varying beta prediction: a bivariate GARCH model, the Schwert and Seguin approach and the Kalman filter method. These techniques were implemented to monthly Morgan Stanley country index data for the period between 1970-1995 and their relative performances were compared. Sample estimation tests for the performance of each of these methods for producing conditional beta demonstrated that GARCH-based risk estimates had the smallest prediction error.

Choudhry and $\mathrm{Wu}$ (2007) scrutinized the estimation of four different GARCH models and the Kalman filter method. The bivariate GARCH, BEKK GARCH, GARCH-GJR and GARCH-X models were used for the four GARCH models applied. The predictive abilities of GARCH models and the Kalman filter method were also compared. The estimation errors based on the weekly stock return of 20 firms in the UK (based on time-varying beta) were used to check the non-sampling predictive ability of both GARCH models and the Kalman method. The findings of the study showed that measures of estimation error strongly supported the Kalman filter. Among the bivariate GARCH type models, GJR-GARCH yielded the most appropriate prediction results.

Abiyev (2015) examined the time-varying betas using weekly data from 2002 to 2013 for the selected portfolio of 20 industries in Turkey. Among the sectors included in the study, the beta was not fixed. In calculating timevarying betas using the M-GARCH, EKK and Kalman filter, it was determined that the Kalman filter method gave the best predictive performance.

Büberkökü and Şahmaroğlu (2016) examined the effect of the transaction volume on time-varying betas, using the daily data of banks traded in BIST from January 1, 2002 to April 8, 2015. It was revealed that beta coefficients were not constant in the study in which time-varying betas were investigated with the M-GARCH method and the relationship between variables was measured with the quantile regression method.

Gümrah and Konuk (2018) investigated whether the betas of banks traded in BIST for the period between 2001 and 2017 changed overtime. Time-varying betas of 12 banks were calculated with the BEKK-GARCH model. It was concluded that the change in the betas of banks over time was due to the benchmark bond interest rates.

According to the common view in the national and international studies examined above, the beta coefficient changes over time. The originality of the study is the use of the FIGARCH model in modeling the volatility because GARCH models do not take into account the long memory behavior in time series. Unlike the literature, timevarying beta estimation is estimated with a fractional model that takes into account long memory behavior.

\section{DATA}

The data included the daily closing price that was traded in the Borsa Istanbul Stock Exchange during January 2009 and September 2019, a total of 129 months. Financial, industrial and banking indices, which were thought to represent the sub-sectors in BIST, the BIST 100 index were representing the market portfolio, and 2-year benchmark bond rates as risk-free interest rates were obtained from investing.com. In the study, the logarithmic return series were used and the logarithmic return series were calculated by the formula $\mathrm{Ln}(\mathrm{Pt} / \mathrm{Pt}-1)$. Although 3-month Treasury bill interest rates have been used to represent the risk-free interest rates in the international literature, the inability to reach the mentioned data set is the most significant limitation of our study.

\section{METHODOLOGY}

This section specifies the empirical methods of the study. It examines the time-varying correlation between BIST100 (market portfolio) index and banking, industrial and financial indices using the Dynamic Equicorrelation (DECO) and Fractionally Integrated GARCH (FIGARCH) model.

There has been much empirical research into the calculation of optimal hedge ratios. The consensus is that the use of MGARCH models yield superior performances, evidenced by lower portfolio volatilities, than either timeinvariant or rolling ordinary least squares (OLS) hedges. In other words, due to the time-varying correlation of multivariate GARCH models, it provides more robust results than static models such as the OLS model in 
calculating the beta coefficient and hedge ratio. Engle (2002) offered the Dynamic Conditional Correlation (DCC) model. The DCC model is suitable for estimates of variability over time. One of the advantages of the DCCGARCH model is that it can specify the possible changes of the conditional correlations over time, allowing us to investigate investors' behaviors dynamically in response to news and innovations.

First of all, the FIGARCH approach is a much more flexible process for the conditional variance. We estimate the conditional volatilities $v_{t}$ from the univariate FIGARCH (p, d, q) process specified in Eq. (1) (Baillie, Bollerslev and Mikkelsen 1996: 8).

$\phi(L)(1-L)^{d} \varepsilon_{t}^{2}=\omega+[1-\beta(L)] v_{t}$

where $(1-\mathrm{L})^{\mathrm{d}}$ is the fractional differencing operator. The long-memory parameter $\mathrm{d}$ satisfies the condition $0 \leq \mathrm{d}$ $\leq 1, \phi(\mathrm{L})$ and $\beta(\mathrm{L})$ are finite-order lag polynomials with roots assumed to lie outside the unit circle. The FIGARCH model implies shocks disperse only at a hyperbolic rate.

Aielli (2013) demonstrates inconsistencies in estimating the covariance matrix $Q_{t}$ in his study $E\left[R_{t}\right] \neq E\left[Q_{t}\right]$ and suggests the following cDCC model for the correlation process:

$Q_{t}=(1-\mathrm{a}-\mathrm{b}) \mathrm{S}^{*}+a\left(Q_{t-1}^{* \frac{1}{2}} u_{t-1} u_{t-1}^{\prime} Q_{t-1}^{* \frac{1}{2}}\right)+b Q_{t-1}$

where $S^{*}$ is the unconditional covariance matrix of $Q^{*}$.

Engle and Kelly (2012) recommend $\boldsymbol{P}_{t}$ modeling by using the cDCC process to access the conditional correlation matrix $Q_{t}$ and then taking the mean of its off-diagonal elements. This approach, which diminishes estimation time, is called the dynamic equicorrelation (DECO) model. The scalar equicorrelation is defined as:

$\rho_{t}^{D E C O}=\frac{1}{n(n-1)}\left(J_{n}^{\prime} R_{t}^{C D C C} J_{n}-n\right)=\frac{2}{n(n-1)} \sum_{i=1}^{n-1} \sum_{j=i+1}^{n} \frac{q_{i j, t}}{\sqrt{q_{i i, t} q_{j j, t}}}$

$q_{i j, t}=\rho_{t}^{D E C O}+a^{D E C O}\left(u_{i, t-1} u_{j, t-1}-\rho_{t}^{D E C O}\right)+b^{D E C O}\left(q_{i j, t}-\rho_{t}^{D E C O}\right)$

which is the (i, j)th element of the matrix $Q_{t}$ from the cDCC model.

We then use this scalar equicorrelation to estimate the conditional correlation matrix:

$$
R_{t}=\left(1-\rho_{t}\right) I_{n}+\rho_{t} J_{n}
$$

Where $\boldsymbol{J}_{n}$ is the $\mathrm{n} \times \mathrm{n}$ matrix of ones and $\boldsymbol{I}_{n}$ is the $\mathrm{n}$ dimensional identity matrix. This assumption of equicorrelation leads to a much simpler probability equation when $\rho_{t}$ is given by Eq. (5):

$$
L=-\frac{1}{T} \sum_{t=1}^{T}\left(\ln \left(1-p_{t}\right)^{n-1}\left(1+(n-1) p_{t}\right)\right)+\frac{1}{1-p_{t}}\left[\sum_{i=1}^{n} \varepsilon_{i, t}^{2}-\frac{p_{t}}{1+(n-1) p_{t}}\left(\sum_{i=1}^{n} \varepsilon_{i, t}^{2}\right)\right]
$$

In this structure, DECO modeling is less burdensome and computationally quicker to estimate, because the inversion of matrix $\boldsymbol{R}_{t}$ is avoided. Furthermore, it becomes probable to represent the comovement of a group of markets with a single dynamic correlation coefficient (Mensi, Al-Yahyaee and Kang 2017: 90). In the time series, the shock lasts for a long time and $\mathrm{ARCH}$ and its derivative models assume that information shocks are quickly eliminated from the market. For this reason, it is preferred to use fractional models instead of short memory models in measuring systematic risk. In calculating the beta coefficient, it will be more accurate to use fractional models that assume that the shocks are gradually eliminated along with the multivariate GARCH models. 


\section{EMPIRICAL FINDINGS}

The descriptive statistics for the BIST 100 (market portfolio) index, sub-indices and the two-year benchmark bond interest are included in Table 1. Then, the time-varying beta graphs (Figures 1,2,3) are given for the banking, industrial and financial sectors. Finally, Table 2 and Table 3 contain long memory test results.

When descriptive statistics were examined, it is seen that the average return was positive for all investment instruments. It is understood from the skewness and kurtosis values that the return of all stock exchanges except the TR2 series was skewed to the left and more flattened than the normal distribution. The benchmark bond interest rate was skewed to the right and more pointed than the normal distribution. According to ADF test statistics, the return series are stationary. JB statistics indicate that the series are non-normal distribution. It is clear from the Q2 and $\mathrm{ARCH}$ test results that there are a significant autocorrelation and existence of ARCH effect in the entire indices for different lags. After examining the descriptive statistics, the time-varying beta was calculated. The bivariate DECO-FIGARCH-std was also estimated based on the assumption.

Here, the necessary calculations were made based on the following formula:

$\beta_{i}=\frac{\operatorname{Cov}(\mathrm{im})}{\sigma_{m}^{2}}$

Table 1. Descriptive Statistics of Return Series

\begin{tabular}{|c|c|c|c|c|c|}
\hline & rXBANK & rXUSIN & rXUMAL & rBIST 100 & rTR2-year \\
\hline Observation: & 2687 & 2687 & 2687 & 2687 & 2687 \\
\hline Mean: & 0.00034694 & 0.000649 & 0.00041504 & 0.00048945 & 0.0000246 \\
\hline Standard Deviation & 0.020498 & 0.012345 & 0.017367 & 0.014536 & 0.01852 \\
\hline Skewness: & -0.17554 & -0.90888 & -0.24682 & -0.41552 & 0.87440 \\
\hline Kurtosis: & 1.9824 & 6.5310 & 2.2604 & 3.1405 & 24.080 \\
\hline Minimum: & -0.11862 & -0.11401 & -0.11295 & -0.11064 & -0.18924 \\
\hline Maximum: & 0.094781 & 0.064551 & 0.077151 & 0.068952 & 0.21182 \\
\hline J-B: & $453.78 * * *$ & $5145.4 * * *$ & $599.30 * * *$ & $1181.5^{* * *}$ & $65261 * * *$ \\
\hline $\operatorname{ARCH}(1-2):$ & $25.878[0.0000]^{* * * *}$ & $48.657[0.0000]^{* * *}$ & $24.670[0.0000]^{* * *}$ & $27.622[0.0000]^{* * *}$ & $243.82[0.0000]^{* * *}$ \\
\hline $\operatorname{ARCH}(1-5):$ & $13.841[0.0000]^{* * *}$ & $31.286[0.0000]^{* * *}$ & $16.653[0.0000]^{* * *}$ & $21.958[0.0000]^{* * *}$ & $144.68[0.0000]^{* * *}$ \\
\hline $\operatorname{ARCH}(1-10):$ & $9.3308[0.0000]^{* * *}$ & $18.191[0.0000]^{* * *}$ & $10.940[0.0000]^{* * *}$ & $13.733[0.0000]^{* * *}$ & $75.254[0.0000]^{* * *}$ \\
\hline$Q(5):$ & $3.64167[0.6020684]$ & $12.7933[0.0253947]^{* *}$ & $3.13525[0.6791430]$ & $4.10235[0.5347764]$ & $84.0435[0.0000000]^{* * *}$ \\
\hline$Q(10):$ & $10.6625[0.3844106]$ & $38.0870[0.0000367]^{* * *}$ & $11.3661[0.3297176]$ & $15.8370[0.1043941]$ & $98.8439[0.0000000]^{* * *}$ \\
\hline$Q(20):$ & $19.8110[0.4698062]$ & $44.4633[0.0013040]^{* * *}$ & $19.7737[0.4721610]$ & $21.4668[0.3701311]$ & $142.304[0.0000000]^{* * *}$ \\
\hline Q2(5): & $91.1836[0.0000000]^{* * *}$ & $192.143[0.0000000]^{* * *}$ & $111.510[0.0000000]^{* * *}$ & $149.999[0.0000000]^{* * * *}$ & $1041.81[0.0000000] * * *$ \\
\hline$Q^{2}(10):$ & $139.719[0.0000000]^{* * *}$ & $232.385[0.0000000]^{* * *}$ & $174.612[0.0000000]^{* * *}$ & $215.222[0.0000000]^{* * *}$ & $1319.24[0.0000000]^{* * *}$ \\
\hline$Q^{2}(20):$ & $185.447[0.0000000]^{* * *}$ & $277.561[0.0000000]^{* * *}$ & $238.370[0.0000000]^{* * *}$ & $291.497[0.0000000]^{* * *}$ & $1476.26[0.0000000] * * *$ \\
\hline ADF & $-29.3585^{* * * *}$ & $-28.2465^{* * *}$ & $-28.9437 * * *$ & $-28.7339 * * *$ & $-27.5495 * * *$ \\
\hline
\end{tabular}

*** \%1 mean ** 5\% significance level. [] represents probability values.

According to the DECO-FIGARCH estimation results, the beta coefficient, the systematic risk indicator of the banking sector, varied depending on time. The banking sector's sensitivity to the market was between 0.89 and 1.16 in the previous years. However, it increased as of the last months of 2018. Thus, it shows that the sensitivity and systematic risk of the banking sector to the market have increased recently. 


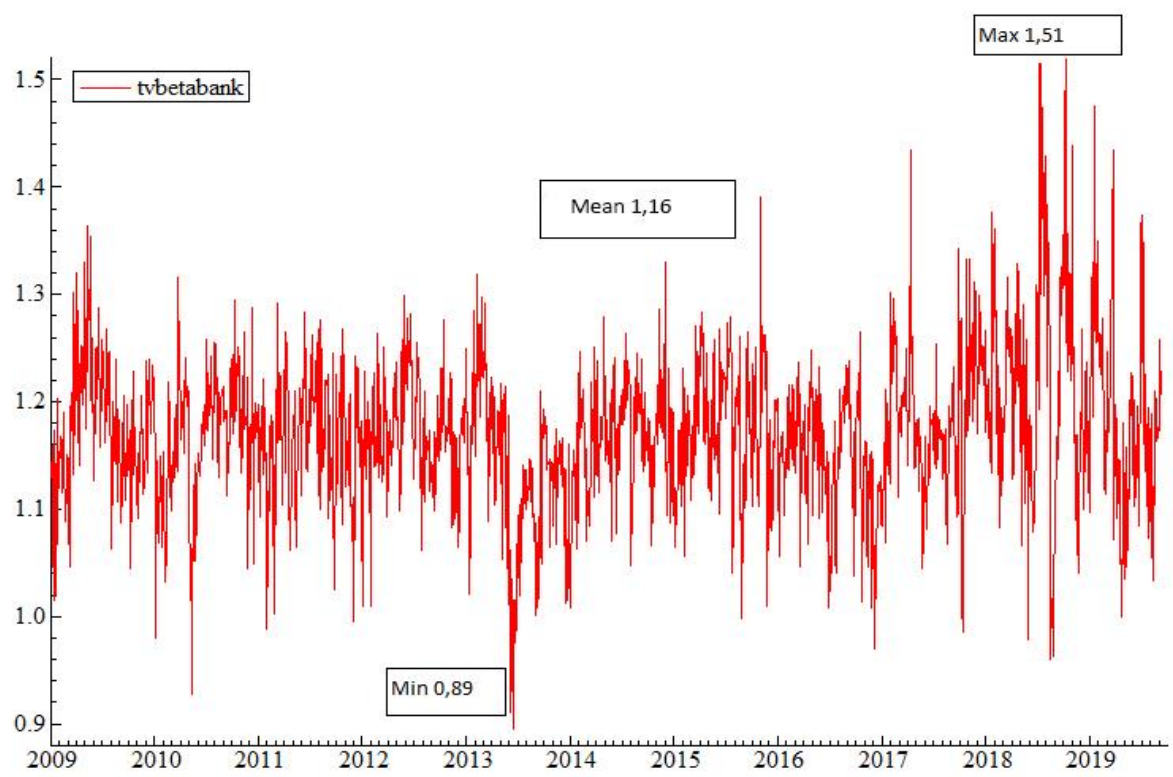

Figure 1. Time-Varying Beta Coefficient for the Banking Sector

The sensitivity of the Industrial Index to the market was 0.86 on average. In other words, the industrial index was not as sensitive to the market in terms of systematic risk as to the banking index. A substantial fluctuation was observed between 2009 and 2011 in the time-varying beta. However, the downward or upward movements in the stock market in the following years did not cause very serious volatility on the Industrial Index. It can be seen that the volatility in the beta coefficient increased in 2018.

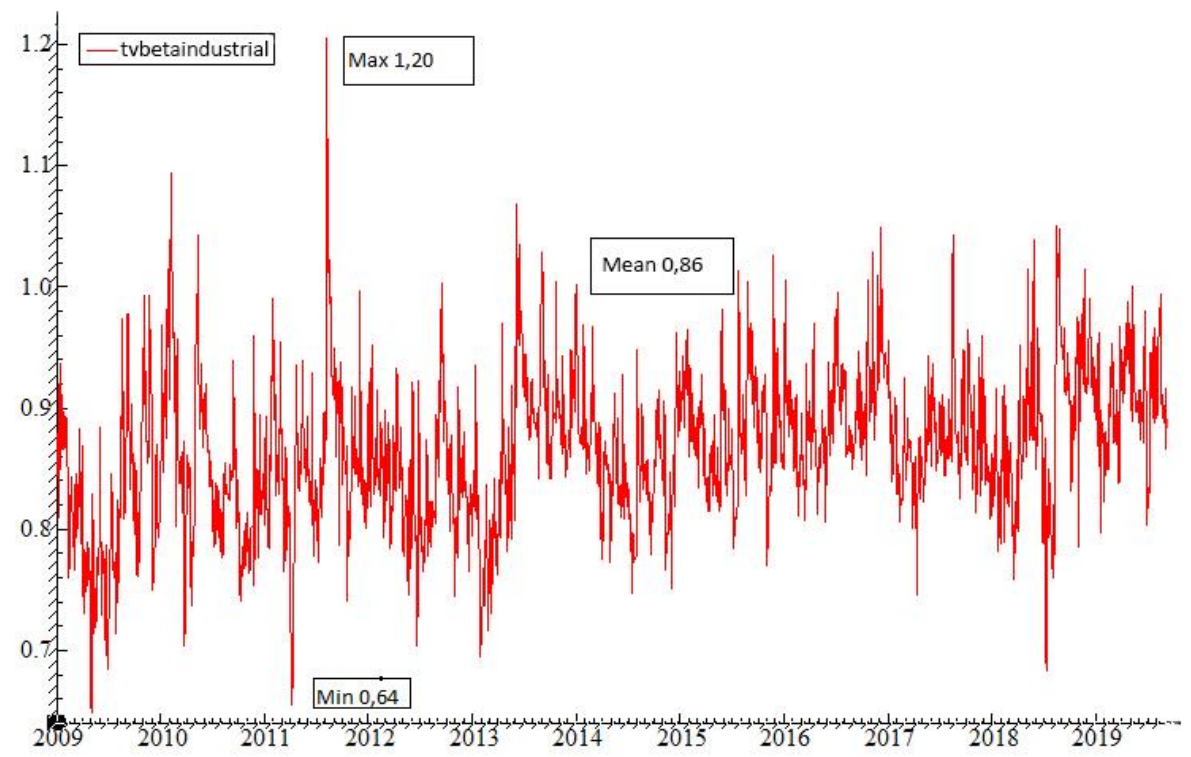

Figure 2. Time-Varying Beta Coefficient for Industrial Sector

A financial index is the closest to the up-or-down movements in the market. The fact that it is very close to representing the market can be understood from its average coefficient of 1.08. The time-varying beta for the financial index varied between 0.93 and 1.24. The financial index's volatility and market sensitivity in beta coefficients, similar to the banking index, appeared to be very high. 


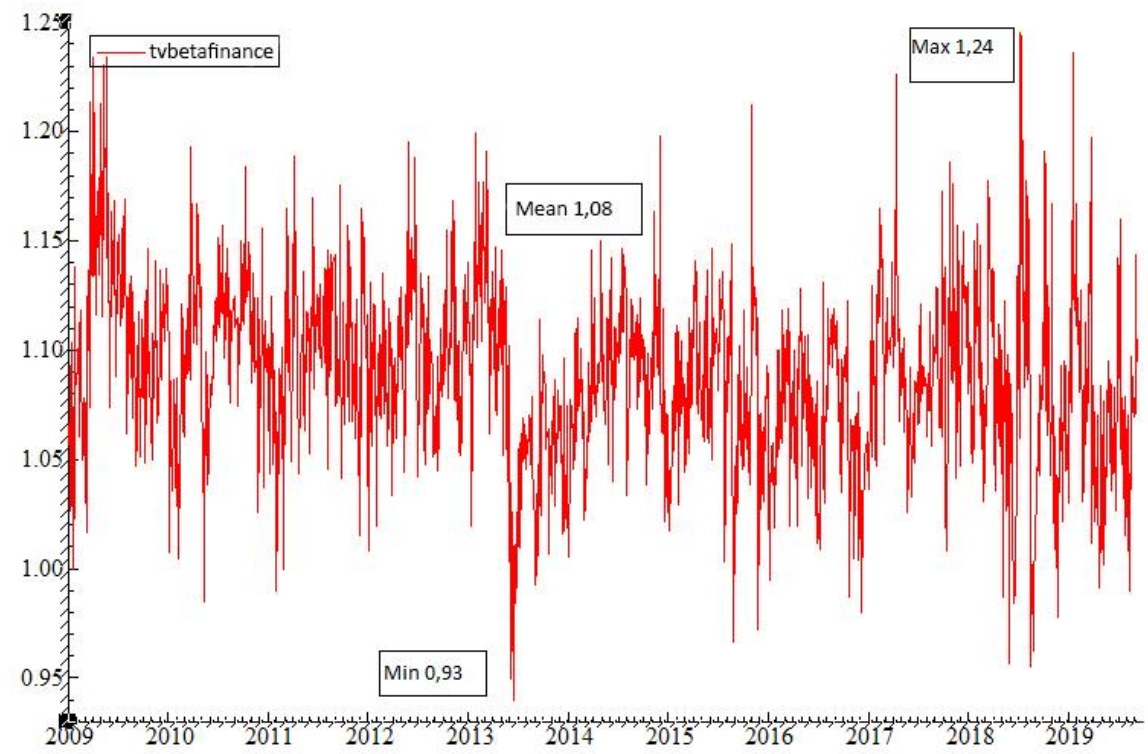

Figure 3: Time-Varying Beta Coefficient for the Financial Sector

After calculating the time-varying betas, the predictability of this coefficient must be investigated with long memory pre-tests. Whether the future beta coefficients and the previous beta coefficients are predictable will help investors to reveal the possibility of obtaining abnormal returns using this information. Therefore, whether subindices are effective in the weak form with a beta coefficient will be indicated.

The existence of long memory in the dataset implies the persistence of observed autocorrelations. Long memory is defined by a hyperbolically decaying autocovariance function. In this study, using the Hurst-Mandelbrot Rescaled Range (R/S) statistics, Lo (1991), Rescaled Range R/S, Geweke and Porter-Hudak (1983) (GPH), and the Robinson and Henry (1999) Gaussian Semiparametric (GSP) test statistics, long-memory components in the returns were tested. These tests have been used in related literature.

Rescaled range statistic R/S, one of the oldest test, was introduced by Hurst (1951). It investigates the existence of long-term memory in time series. Mandelbrot and Wallis (1969) discovered many series with endless memory. Mandelbrot (1971) recommended that R/S analysis can be used in financial researches. The Hurst exponent is used as a measure of long-term dependence for given non-periodic cycles, and points out the average duration of the dependency may last. Fundamentally, Rescaled range statistic R/S is the range of partial sums of deviations of a time series from its mean scaling with its standard deviation. Therefore, Hurst exponent $\mathrm{H}$ stands for the scaling behavior of the range of cumulative departures of a time series from its mean. Formally, the range $\mathrm{R}$ of a time series $\{\mathrm{xt}\}, \mathrm{t} \mathrm{T}=1, \ldots$, is determined as:

$$
\left(\frac{R}{S}\right)_{\tau}=\frac{1}{S_{\tau}}\left[\max _{1 s \leq t \leq \tau} \sum_{k=1}^{t}\left(x_{k}-\overline{x_{\tau}}\right)-\min _{1 s \leq t \leq \tau} \sum_{k=1}^{t}\left(x_{k}-\overline{x_{\tau}}\right)\right]
$$

Other approaches used to determine long-memory are semi-parametric and parametric methods. Geweke and Porter-Hudak (1983) recommended a semi-non-parametric approach to test for long memory in the sense of the fractionally integrated process. Let $\Gamma_{t}$ be the return series. The GPH estimator of the long memory parameter $\mathrm{d}$ for $\Gamma_{\mathrm{t}}$ can be then determined using the following periodogram:

$$
\log \left[I_{X}\left(\lambda_{s}\right)\right]=\alpha-\beta \log \left[4 \sin ^{2}\left(\frac{\lambda_{s}}{2}\right)\right]+\varepsilon_{s}
$$

GPH test for the null hypothesis "there is no long memory $(\mathrm{d}=0)$ ".

Gaussian Semiparametric prediction method, introduced by Robinson and Henry (1999), is based on the specification of the shape of the spectral density of the time series. The GSP estimate depends on the m parameter. 
When $\mathrm{m}[(\mathrm{T}-1) / 2]$ is less than or equal to $\mathrm{T} \rightarrow \infty(1 / \mathrm{m}+\mathrm{m} / \mathrm{T}) \rightarrow 0$. GSP prediction of $\mathrm{d}$ is obtained by minimizing the following function: (Barışı ve Çevik, 2008, 13)

$$
r(d)=q(\breve{g}, d)-1=\ln m^{-1} \sum_{j=1}^{m} \frac{I\left(\lambda_{j}\right)}{\lambda_{j}^{-2 d}}-2 d m^{-1} \sum_{j=1}^{m} \ln \lambda_{j}
$$

where

$$
q(\breve{g}, d)=m^{-1} \sum_{j=1}^{m}\left(\frac{I\left(\lambda_{j}\right)}{\breve{g} \lambda_{j}^{-2 d}}+\ln \breve{g} \lambda_{j}^{-2 d}\right) \breve{g}=m^{-1} \sum_{j=1}^{m} \lambda_{j}^{2 d} I\left(\lambda_{j}\right)
$$

\begin{tabular}{|c|c|c|c|c|}
\hline \multicolumn{2}{|c|}{ BETABANK } & d statistics & $t\left(H_{0}: d=0\right)$ & Probability \\
\hline \multicolumn{5}{|c|}{ GPH } \\
\hline & 0.5 & .157899 & 1.6678 & 0.102 \\
\hline & 0.55 & $.281213 * * *$ & 3.5347 & 0.001 \\
\hline \multirow[t]{3}{*}{ Power } & 0.6 & $.368197 * * *$ & 6.1922 & 0.000 \\
\hline & 0.65 & $.409804 * * *$ & 8.4112 & 0.000 \\
\hline & 0.7 & $.447852 * * *$ & 11.0835 & 0.000 \\
\hline \multicolumn{2}{|c|}{ BETAINDUSTRIAL } & d statistics & $t(H O: d=0)$ & Probability \\
\hline \multicolumn{5}{|c|}{ GPH } \\
\hline \multirow{5}{*}{ Power } & 0.5 & $.323966 * * *$ & 2.9446 & 0.005 \\
\hline & 0.55 & $.399293 * * *$ & 4.6559 & 0.000 \\
\hline & 0.6 & $.468641 * * *$ & 7.3094 & 0.000 \\
\hline & 0.65 & $.44417 * * *$ & 8.8122 & 0.000 \\
\hline & 0.7 & $.48763^{* * *}$ & 11.6426 & 0.000 \\
\hline \multicolumn{2}{|c|}{ BETAFINANCE } & d statistics & $t\left(H_{0}: d=0\right)$ & Probability \\
\hline \multicolumn{5}{|c|}{ GPH } \\
\hline \multirow{5}{*}{ Power } & 0.5 & $.245299 * *$ & 2.2303 & 0.030 \\
\hline & 0.55 & $.330189 * * *$ & 3.9000 & 0.000 \\
\hline & 0.6 & $.370412 * * *$ & 5.9627 & 0.000 \\
\hline & 0.65 & $.425908 * * *$ & 8.2662 & 0.000 \\
\hline & 0.7 & $.447744 * * *$ & 10.9479 & 0.000 \\
\hline
\end{tabular}

Table 2. GPH Long Memory Test Results

*** \%1 mean $* * 5 \%$ significance level. [] represents probability values.

According to the GPH long memory test results presented in Table 2, the banking sector beta was in the range of d-long memory parameter 0.16 to 0.45 , the industrial sector 0.32 to 0.48 and the financial sector 0.24 to 0.44 . Time-varying betas of sub-sectors exhibited long memory. These results show that the series have a fractal structure.

Lo's modified R/S test was performed and the results are given in Table 3. In Lo's Modified R / S test, the hypothesis that series have no long-term dependency was tested. According to the test results, test statistics were greater than the critical value ranges. The time-varying beta calculated for Beta-bank, beta-financial and betaindustrial had a long memory. This situation coincides with the results of GPH. 
Süleyman Demirel Üniversitesi Vizyoner Dergisi, Yıl: 2020, Cilt: 11, Sayı: Ek, 200-210.

Süleyman Demirel University Visionary Journal, Year: 2020, Volume: 11, No: Supplement, 200-210.

Table 3. Lo R/S Test Results

\begin{tabular}{cccc}
\hline Beta-bank & Test statistics & $2.98 * * *$ \\
\hline Beta-industrial & Test statistics & $4.41 * * *$ \\
\hline Beta-financial & Test statistics & $4.19 * * *$ \\
\hline & $\% 90$ & {$[0.861-1.747]$} & \\
Critical Value & $\% 95$ & {$[0.809-1.862]$} & \\
\hline & $\% 99$ & {$[0.721-2.098]$} & \\
\hline
\end{tabular}

*** \%1 mean ** 5\% significance level. [] represents probability values.

Third, the GSP test, proposed by Robinson and Henry (1999), was applied for long memory behaviors in the beta. The parameter d was statistically significant at $1 \%$. d-parameter results were 0.81 for beta-bank, 0.84 for betaindustrial and 0.87 for beta-financial. Based on the results of the research conducted through 3 different tests, it was concluded that the time-varying betas have long memory behavior. These results show that future beta (systematic risk indicator) can be predicted by examining the betas of past observations. Therefore, it indicates that the sub-indices mentioned are an index with a fractal structure.

\section{CONCLUSION}

The relationship between return and risk determines the quality of investment and investment vehicles. It is crucial to estimate the cost of capital as much as the expected return for the investor. Investors are unable to reduce the risk by merely diversifying the portfolio against potential risk. They should also consider the direction and degree of the relationship between the investment vehicles.

Investors have recently been more sensitive to calculate their risks compared to the past. Therefore, many studies have been conducted to make future estimations with historical data. In the first studies, it was assumed that the beta coefficient was used as a systematic risk indicator with CAPM, and the correlation between the market and the risky investment vehicle remained constant over time. However, the studies pioneered by Blume (1971) and Bollerslev (1988) show that the beta coefficient will change because of the time-dependent correlation changes. In addition to the studies, time-varying beta coefficients are calculated with models that consider the existence of both time-varying and long memory.

Using the data of financial, industrial and banking sectors, thought to represent sub-sectors in BIST, from 01.01.2009 to 09.09.2019, the time-varying beta coefficient was determined by using the DECO-FIGARCH model. GPH, Lo R/S, and GSP tests were also used to examine the long memory behavior of the beta coefficient. According to DECO-FIGARCH prediction results, the beta coefficient of all three sub-indices varied depending on time. The closest index to the up-or-down movements in the market was the financial index (average 1.08), and the volatility and sensitivity of the banking index to the market (average 1.16) were similarly high. The average sensitivity of the businesses in the industrial index to the market was 0.86 , which meant they were not as sensitive to the market in terms of systematic risk as to the businesses in the financial and banking sectors. In literature, many studies have shown that beta coefficients do not remain constant and have changed over time. The results were compatible with the results obtained by Abiyev (2015), Büberkökü ve Şahmaroglu (2016), Gümrah and Konut (2018) in national studies in which the time-varying beta was detected with multivariate GARCH and by Choudhry and Wu (2007), Brooks et al. (1998), Faff et al. (1998) in international studies in which the time-varying beta was analyzed. Research over three different tests for long memory behaviors in the Beta coefficient has shown that the coefficient follows long memory behavior (fractal) and the future can be predicted by examining the beta coefficients of the past calculated on historical returns in the sub-indices. Choudhry (2001) studied three developing stock exchanges in Asia and found the time-varying beta coefficient with a long memory by using GPH and Robinson tests. Similar to previous studies (Jagannathan and Wang) (1996), the study gives better results than unconditional (static) models of time-varying dynamic beta models.

In this study, which is carried out sub-indices in the capital market, it is concluded that time-varying betas can be predicted by examining the past observation; therefore, the weak-form efficiency contradicts market activity. An investor who wants to invest based on sub-indices may predict the beta coefficients of the future by examining the betas of the past. Thus, investors may have the opportunity to obtain abnormal returns from their investments. In 
Süleyman Demirel Üniversitesi Vizyoner Dergisi, Yıl: 2020, Cilt: 11, Sayı: Ek, 200-210.

Süleyman Demirel University Visionary Journal, Year: 2020, Volume: 11, No: Supplement, 200-210.

future studies, the research can expand to include other Borsa Istanbul sub-indices, and especially portfolio diversification and hedging effectiveness will contribute to investors.

\section{REFERENCES}

Abiyev, V. (2015). Time-varying beta risk and its modeling techniques for Turkish industry portfolios. Iktisat Işletme ve Finans Dergisi, 30(352), 79-108.

Aielli, G.P. (2013). Dynamic conditional correlation: On properties and estimation. Journal of Business and Economic Statistic, 31(3), 282-299.

Baillie, R. T., Bollerslev, T. and Mikkelsen, H. O. (1996). Fractionally integrated generalized autoregressive conditional heteroskedasticity. Journal Of Econometrics, 74(1), 3-30.

Barışık, S. and Çevik, E. İ. (2008). Yapısal kirilma testleri ile Türkiye'de işsizlik histerisinin analizi: 1923-2006 dönemi. KMU IIBF Dergisi, 10(14), 1-26.

Blume, M. (1971). On the assessment of risk. The Journal of Finance, 26(1) , 1-10.

Bollerslev, T., Engle, R. F. and Wooldridge, J. M. (1988). A capital asset pricing model with time varying covariances. Journal of Political Economy, 96(1), 116-131.

Brealey, R. A., Myers, S. and Allen, F., (2014). Principles of corporate finance. 11th ed., New York: McGrawHill Companies.

Brooks, R. D., Faff, R. W. and McKenzie, M. D. (1998). Time-varying beta risk of Australian industry portfolios: A comparison of modelling techniques. Australian Journal of Management, 23(1), 1-22.

Brooks, R., Faff, R. and McKenzie, M. (2002). Time-varying country risk: An assessment of alternative modeling techniques. European Journal of Finance, 8, 249-279.

Brooks, R., Faff, R. and Ariff, M. (1998). An investigation into the extent of beta instability in the singapore stock market. Pacific-Basin Finance Journal, 6, 87-101.

Büberkökü, Ö. and Şahmaroğlu, S. (2016). Beta katsayılarındaki değişimin açıklanmasında işlem hacminin etkisinin incelenmesi: Banka hisselerine dayalı bir analiz. İsletme Bilimi Dergisi, 4, 1-28.

Choudhry, T. (2001). The long memory of time-varying beta: Examination of three emerging asian stock markets. Managerial Finance, 27(1/2), 5-14.

Choudhry, T. and Wu, H. (2007). Time-varying beta and forecasting Uk company stock returns: Garch models vs Kalman filter method. Southampton: University of Southampton Press.

Elton, E., Gruber, M., Brown, S. and Goetzmann, W. (2014). Modern portfolio theory and investment analysis. New Jersey: John Wiley and Sons Inc.

Engle, R. and Kelly, B. (2012). Dynamic equicorrelation. Journal of Business and Economic Statistics, 30, 212228

Faff, R. , Lee, W. and John, H. (1992). Time stationarity of systematic risk: Some Australian evidence. Journal of Business Finance and Accounting, 19(2), 253-270.

Geweke J. and Porter-Hudak S. (1983). The estimation and application of long memory time series models. Journal of Time Series Analysis, 4, 221-238.

Gümrah, Ü. and Konuk, S. (2018). Zamanla değişen beta: Borsa İstanbul bankacılık sektörü uygulaması. Ekonomik ve Sosyal Araştırmalar Dergisi, 14(1), 51-66.

Hurst H. (1951). Long term storage capacity of reservoirs. Transactions of the American Society of Civil Engineers, 116, 770-799.

Jagannathan, R. and Wang, Z. (1996). The conditional capm and the cross-section of expected returns. The Journal of Finance, 51(1), 3-53. 
Lintner, J. (1965). The valuation of risk assets on the selection of risky investments in stock portfolios and capital budgets. Review of Economics and Statistics, 47, 13-37.

Lo, A. W. (1991). Long term memory in stock market prices. Econometrica, 59, 1279-1313.

Mandelbrot, B. B, and Wallis, J. R. (1969). Some long-run properties of geophysical records. Water Resouces Research, 5(2), 321-340.

Mandelbrot, B. B. (1971). When can price be arbitraged efficiently? A limit to the validity of the random walk and martingale models. Review of Economics and Statistics, 53(3), 225-236.

Mensi, W. Yahyaee, K. and Kang, S. (2017). Time-varying volatility spillovers between stock and precious metal markets with portfolio implications. Resources Policy, 53, 88-102.

Mossin, J. (1966). Equilibrium in a capital asset market. Econometrica: Journal of the econometric societybeka, 768-783.

Robinson, P. M. and Henry, M. (1999). Long and short memory conditional heteroskedasticity in estimating the memory parameter of levels. Econometric Theory, 15(03), 299-336.

Robinson, P.M. (1995). Gaussian semiparametric estimation of long range dependence. Annals of Statistics, 23, 1630-1661.

Ross, S., Westerfield, R. and Jaffe, J. (2013). Corporate finance 10th ed. New York: The McGraw-Hill Companies.

Sharpe, W. F. (1964). Capital asset prices: A theory of market equilibrium under conditions of risk. The Journal of Finance, 425-442. 